\title{
Reliabilita testování maximální volní kontrakce horních a dolních končetin a trupu na izometrickém dynamometru
}

\section{The reliability of maximal voluntary contraction testing of upper and lower body limbs and trunk on isometric dynamometer}

\author{
Barbora Strejcová, Jiří Baláš, Ladislav Čaba, Miroslav Kadlec, Vladimír Süss
}

Fakulta tělesné výchovy a sportu Karlovy univerzity, Praha

\begin{abstract}
Abstrakt
Cílem této studie bylo určení reliability měrení maximální volní kontrakce na izometrickém dynamometru Vishay Tedea-Huntleigh Model 1042 ve vybraných kloubech horních a dolních končetin při flexi

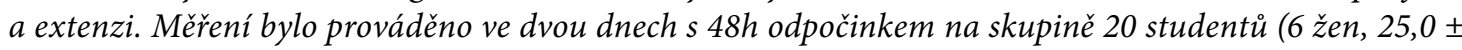
2,3 let; 14 mužư 24,4 \pm 2,7 let). Reliabilita byla hodnocena vnitrotř́dním korelačním koeficientem reliability (intraclass correlation coefficient, ICC), modelem $(3, k)$ a Pearsonovým koeficientem ( $r$ ). ICC pro flexi a extenzi v loketním kloubu (LK) se pohyboval v rozmezi 0,92-0,96 ( $r=0,62-0,93)$, pro flexi a extenzi $v$ kolenním kloubu (KK) dosahoval ICC 0,91-0,95 $(r=0,87-0,92)$ a pro úklon a předklon trupu byl ICC roven 0,85 a 0,75 .
\end{abstract}

\begin{abstract}
The aim of this study was to assess the reliability of isometric strength measurement in flexion and extension in the chosen joints of upper and lower body extremities using the dynamometer Vishay Tedea-Huntleigh Model 1042. The measurements were undertaken in two days with the rest period of forty-eight hours between sessions. Twenty sport students took part in the study (6 females, $25 \pm 2,3$ years; 14 males, 24,4 $\pm 2,7$ years). We used the intraclass correlation coefficient (ICC) model $(3, k)$ and Pearson's $r$ to assess the reliability. ICC of elbow flexion and extension was 0,92-0,96 $(r=0,62-0,93)$, knee flexion and extension 0,91-0,95 ( $r=0,87-0,92)$, trunk abduction and flexion were 0,85 and 0,75 .
\end{abstract}

Klíčová slova: Maximální izometrická síla, reliabilita, vnitrotřídní korelační koeficient.

Key words: $\quad$ Maximal isometric strength, reliability, intraclass correlation coefficient.

Studie byla podpořena výzkumným záměrem MSM 0021620864 a specifickým výzkumem SVV-2010-261602.

\section{Úvod}

K měření maximální izometrické volní kontrakce používáme izometrické dynamometry jako prostředek ke zjištění aktuálního stavu svalové síly (měření projevu maximálního svalového výkonu, průměrné práce). Izometrická síla se vyznačuje maximální kontrakcí svalu působící proti pevnému odporu, kde je upevněn tenzometrický snímač.

V současné době se objevuje stále více studií zabývajících se reliabilitou měření izometrické a izokinetické síly (Phillips et al., 2000; Strejcová et al., 2010). Reliabilita je jednou ze základních vlastností testovacích procedur. Na základě definice reliability podle Blahuše (1996) můžeme test považovat za reliabilní, pokud rozptyl jeho chyb je malý. Používání koeficientů reliability měření izometrické síly je rozporuplné a není zcela jasné.

Nejčastěji se setkáváme s koeficientem vnitrotřídní korelace (intraclass correlation coefficient, ICC) nebo Pearsonovým korelačním koeficientem $r$, který se někdy označuje jako interclass coefficient of correlation (Thomas a Nelson, 1996). Tyto dva koeficienty se od sebe liší podle typu testovacích procedur, počtu testujících a testovaných. Pearsonův koeficient $r$ lze použít pouze na dvě měření, není citlivý na změny průměrů mezi pokusy a zároveň není citlivý na homogenitu skupiny (Baumgartner, 2000; Thomas a Nelson, 1996). 
ICC zahrnuje systematické chyby měření (změny průměrů), ale také chyby náhodné (motivace, únava, načasování a ostatní okolnosti působící př̀i měření) (Atkinson a Nevill, 1998, 2000; Hopkins, 2000; Weir, 2005). V případech, kdy se jedná o malý heterogenní vzorek, je vhodné použít ICC. Pokud je výzkumná skupina homogenní (malý vnitroskupinový rozptyl), pak je nízká hodnota ICC a naopak.

Jako absolutní hodnotitel věcné významnosti výsledků měření se používá střední chyba měření (Hendl, 2004; Hopkins, 2000; Weir, 2005). Tento koeficient slouží k posouzení absolutních změn při hodnocení výsledků experimentálních programů. Je však závislý na hodnotách koeficientů reliability, jak vyplývá ze vzorce.

Mezi dynamometry určující svalové výkony můžeme řadit několik zmíněných dynamometrů měřících výstup maximální izometrické svalové kontrakce, jako například Biodex (Mcintire et al., 2007; Peolsson et al., 2001), Kin-Com (Cannon et al., 2008; Phillips et al., 2000; Smith et al., 2001), Con-Trex (Maffiuletti et al., 2007).

Jednoduché izometrické př̌istroje používané pro zjištění okamžitého výkonu jsou ručně držené dynamometry, které jsou velmi lehké a přenosné (Dawson et al., 1992; Vermeulen et al., 2005). Ručně držený dynamometr je přiložen na měřenou část končetiny proti směru pohybu a tlačí se proti snímači dynamometru maximálním úsilím. Na tomto základě jsou používány fixní izometrické dynamometry, které mají snímače nastálo upevněny, upravuje se pouze poloha testovaného (Heyward, 2010).

Cílem naší studie bylo ověřit reliabilitu měření maximální izometrické síly vyvinuté při flexi a extenzi ve vybraných kloubech horních a dolních končetin a trupu (flexe, extenze v LK, KK, předklon a úklony trupu) na dynamometru s tenzometrickými snímači.

\section{METODIKA}

\section{Výzkumný soubor}

Měření se zúčastnilo 20 studentů tělovýchovného studijního směru. Jednalo se o 6 žen (věk 25,0 02,3 let, hmotnost 55,8 $\pm 5,3 \mathrm{~kg}$, výška $1,63 \pm 0,06 \mathrm{~m}$ ) a 14 mužů (věk $24,4 \pm 2,7$ let, hmotnost $74,4 \pm 6,4 \mathrm{~kg}$ a výška $1,79 \pm 0,05 \mathrm{~m}$ ), kteři aktivně sportovali 2-3krát týdně. U všech byly předpokládány zkušenosti se silovým tréninkem a jinými pohybovými aktivitami. Účastníci nevykonávali 2 dny před testováním žádný náročný pohybový trénink. Před měřením ani během něho účastníci nezmínili žádné okolnosti, které mohly ovlivnit výsledky měření. Všichni účastníci byli informováni o průběhu testování a podepsali souhlas $\mathrm{k}$ měření.

\section{Postup měření}

Pro zjištění reliability měření maximální volní izometrické kontrakce ve vybraných kloubech jsme použili metody test-retest, dvě opakování téhož testu (Baumgartner a Jackson, 2003; Blahuš, 1976; Hendl, 2004; Měkota a Blahuš, 1983; Weir, 2005).

Maximální izometrická síla byla měřena na dynamometru sestrojeném v Biomedicínské laboratoři s tenzometrickými snímači (Vishay Tedea-Huntleigh Model 1042). Testy byly prováděny v dopoledních hodinách po 5 minutovém rozcvičení. Mezi testem a retestem uplynulo $48 \mathrm{~h}$ a mezi pohybovými úkoly byla 2 minutová přestávka. Střídala se pravá a levá končetina. Pokaždé byly provedeny 2 pokusy, do výsledku se započítával ten lepší. Poloha účastníka byla zaznamenána pomocí fotoaparátu pro stejné nastavení lavice při retestu. Izometrická lavice byla nastavitelná, a proto mohly být dodržovány pravé úhly dvou sousedních segmentů při měření flexe a extenze v LK (obr.1) a KK. Součástí izometrické lavice nejsou upínací pásy, které by fixovaly polohu jedince při daném pohybu. $\mathrm{K}$ měření předklonu a úklonu (obr. 2) ve vzpř́ímeném stoji byl použit sešitý popruh, který byl zapojen na snímač dynamometru. 
Obrázek 1, 2: Pozice účastníka při flexi LK pravé končetiny, pozice účastníka při úklonu vpravo s použitím sešitého pásu
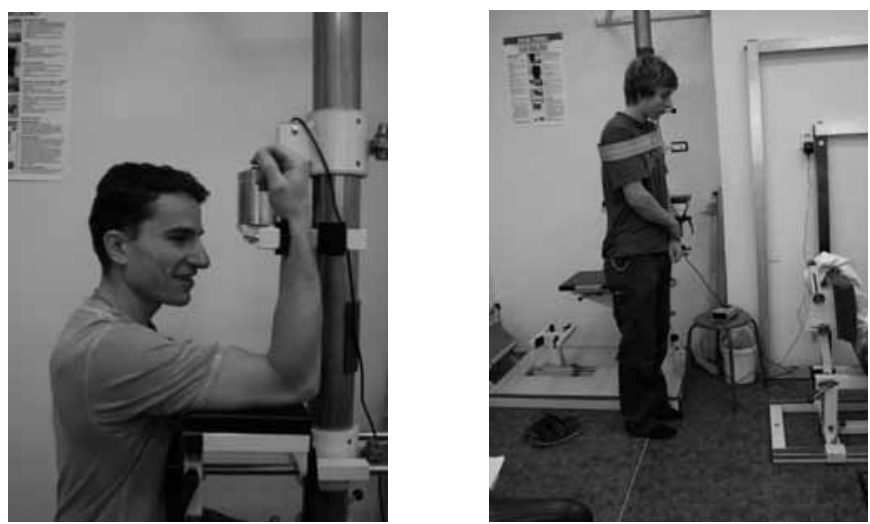

\section{Vyhodnocení výsledků}

Pro výpočet reliability byl použit koeficient vnitrotřídní korelace ICC model $(3, \mathrm{k})$ neboli 2-way mixed model (Baumgartner a Jackson, 2003; Shrout a Fleiss, 1979; Weir, 2005). Pro srovnání uvádíme také Pearsonův korelační koeficient $r$. K vyhodnocení věcné významnosti výsledků jsme použili stř̌ední chybu měření (SEM) jako absolutního hodnotitele podle vzorce SEM=SD* 1 1-ICC, kde SD je směrodatná odchylka měření a ICC zmíněný koeficient reliability (Hendl, 2004; Hopkins, 2000; Weir, 2005). K vyhodnocení naměřených dat byl použit statistický program SPSS (verze 17.0).

\section{Výsledky}

V tabulce 1 uvádíme ICC, $r$ a střední chybu měření (SEM) pro maximální izometrickou sílu ve vybraných kloubech horních a dolních končetin vsedě a vestoje pro měření maximální izometrické síly trupu. Ve všech př́ípadech Pearsonův koeficient $(r)$ dosahuje nižších hodnot než ICC. Pohybuje se v rozmezí $0,61-0,93$. Nejnižší $r$ dosahuje úklon vpravo $(r=0,61)$ a extenze v pravém LK, a to jen 0,62 . Nejvyšší hodnotu $r$ dosahuje extenze v levém LK $(r=0,93)$. Reliabilita měření ověřovaná ICC dosahuje hodnot 0,75 (úklon vpravo) až 0,96 (extenze v levém LK).

Tabulka 1: Reliabilita testování maximální izometrické síly ve vybraných kloubech horních a dolních končetin a pro pohyby trupu (předklon a úklon); P1, L1 - test pravé a levé končetiny, P2, L2 - retest pravé a levé končetiny, LK - loketní kloub, KK - kolenní kloub.

\begin{tabular}{|c|c|c|c|c|c|}
\hline Pohyb.úkol & $\begin{array}{c}\text { Prům. výkon } \\
(\mathrm{kg})\end{array}$ & $\begin{array}{l}\text { SD } \\
(\mathrm{kg})\end{array}$ & ICC $^{*}$ & $r^{* *}$ & $\begin{array}{l}\text { SEM } \\
(\mathrm{kg})\end{array}$ \\
\hline FlexeP1LK & 29,6 & 8,84 & \multirow{2}{*}{0,92} & \multirow{2}{*}{0,85} & \multirow{2}{*}{2,58} \\
\hline FlexeP2LK & 29,97 & 9,04 & & & \\
\hline FlexeL1LK & 28,85 & 8,61 & \multirow{2}{*}{0,92} & \multirow{2}{*}{0,85} & \multirow{2}{*}{2,38} \\
\hline FlexeL2LK & 28,71 & 7,77 & & & \\
\hline ExtenzeP1LK & 13,17 & 4,29 & \multirow{2}{*}{0,76} & \multirow{2}{*}{0,62} & \multirow{2}{*}{2,26} \\
\hline ExtenzeP2LK & 15,3 & 5,02 & & & \\
\hline ExtenzeL1LK & 14,2 & 4,6 & \multirow{2}{*}{0,96} & \multirow{2}{*}{0,93} & \multirow{2}{*}{0,96} \\
\hline ExtenzeL2LK & 16,13 & 5,21 & & & \\
\hline
\end{tabular}




\begin{tabular}{|c|c|c|c|c|c|}
\hline Pohyb.úkol & $\begin{array}{c}\text { Prům. výkon } \\
(\mathrm{kg})\end{array}$ & $\begin{array}{l}\text { SD } \\
(\mathrm{kg})\end{array}$ & ICC $^{*}$ & $r^{\star *}$ & $\begin{array}{r}\text { SEM } \\
(\mathbf{k g})\end{array}$ \\
\hline FlexeP1KK & 24,75 & 10,86 & \multirow{2}{*}{0,95} & \multirow{2}{*}{0,92} & \multirow{2}{*}{2,21} \\
\hline FlexeP2KK & 25,83 & 9,82 & & & \\
\hline FlexeL1KK & 24,7 & 10,71 & \multirow{2}{*}{0,95} & \multirow{2}{*}{0,9} & \multirow{2}{*}{2,34} \\
\hline FlexeL2KK & 25,7 & 9,6 & & & \\
\hline ExtenzeP1KK & 55,11 & 22,5 & \multirow{2}{*}{0,90} & \multirow{2}{*}{0,86} & \multirow{2}{*}{6,17} \\
\hline ExtenzeP2KK & 51,58 & 16,17 & & & \\
\hline ExtenzeL1KK & 51,02 & 19,27 & \multirow{2}{*}{0,91} & \multirow{2}{*}{0,87} & \multirow{2}{*}{5,05} \\
\hline ExtenzeL2KK & 48,44 & 14,85 & & & \\
\hline Předklon1 & 65,78 & 18,45 & \multirow{2}{*}{0,85} & \multirow{2}{*}{0,74} & \multirow{2}{*}{6,86} \\
\hline Předklon2 & 57,05 & 16,83 & & & \\
\hline ÚklonP1 & 65,53 & 16,67 & \multirow{2}{*}{0,75} & \multirow{2}{*}{0,61} & \multirow{2}{*}{7,49} \\
\hline ÚklonP2 & 56,44 & 13,04 & & & \\
\hline ÚklonL1 & 64,11 & 15,99 & \multirow{2}{*}{0,85} & \multirow{2}{*}{0,74} & \multirow{2}{*}{6,06} \\
\hline ÚklonL2 & 58,24 & 15,33 & & & \\
\hline
\end{tabular}

* Intraclass correlation coefficient

**Pearsonův korelační koeficient mezi testem a retestem.

Z tabulky 1 je zřejmá vysoká pravolevá shoda ICC i $r$ pro flexi pravé horní končetiny a pro flexi a extenzi dolních končetin. Extenze LK pro pravou a levou končetinu vykazuje rozdílné hodnoty ICC i $r$ ( $r=$ 0,62 a 0,$93 ; \mathrm{ICC}=0,76$ a 0,96 ). Dalším př́padem, ve kterém se liší hodnoty obou koeficientů reliability, je úklon vpravo a úklon vlevo. V ostatních př́padech se ICC i $r$ téměř shodují (flexe LK, flexe KK, extenze $\mathrm{KK}$, předklon a úklon trupu vlevo) - zřejmé z tabulky 1.

\section{Diskuse}

Pokud se jedná o měření silových schopností prostřednictvím dynamometrů, můžeme reliabilitu jednotlivých testů srovnávat na základě velikosti jejich korelačních koeficientů $(r$, ICC) s ohledem na velikost a charakteristiku skupiny. Velikost těchto dvou koeficientů a současně střední chyba měření je závislá na věku jedinců, pohlaví, psychickém stavu, zkušenosti s testováním a na použitém dynamometru (Baumgartner a Jackson, 2003). Ve všech př́ípadech se objevily vyšší hodnoty ICC než $r$ jako důsledek heterogenity skupiny $\mathrm{z}$ hlediska pohlaví a současně velikosti maximální izometrické síly. $\mathrm{Z}$ hlediska věku se jednalo o homogenní skupinu. Ve většině př́ípadů se shodovaly výsledky reliability pravé a levé končetiny. Jediný větší rozdíl koeficientů realiability se objevil při extenzi v LK mezi pravou a levou končetinou. Vyšší hodnota ICC a $r$ byla zaznamenána při měření levého LK. Dủvodem mohlo být nedostatečné zacvičení testovaných, kdy první pokusy byly uskutečněny vždy na pravé končetině. Vysvětlení není zcela jednoznačné, protože všichni testovaní uvedli pravou horní končetinu jako dominantní.

\section{Reliabilita měření v loketním a ramenním kloubu}

Dawson, Croce et al. (1992) využili k měření maximální volní kontrakce, při flexi a extenzi horních končetin, ručně držený dynamometr. Děti ve věku 8-10 let tlačily maximálním úsilím proti snímačům dynamometru. Pearsonův koeficient reliability pro flexi a extenzi u dominantní 0,77 a 0,80 u nedominantní končetiny se nalézal v rozmezí $0,75-0,79$ pro chlapce. Pro dívky bylo $r$ pro dominantní končetinu a nedominantní 0,72-0,83 a 0,73-0,87 (Dawson et al., 1992). Nízké hodnoty mohly být způsobeny věkem jedinců (8-10 let). V našem př́ípadě bylo $r(0,85)$ pro flexi v LK vyšší a pro extenzi pravé končetiny nižší 
$(0,62)$ a v př́padě levé končetiny se naopak rovnalo hodnotě 0,93 . Naše hodnoty byly vyšší z důvodu starších účastníků souboru $(24,7 \pm 2,5$ let), ale také zjištováním reliability bez ohledu na pohlaví.

Ručně držený dynamometr (MicroFET2) použil ve své práci také Vermeulen et al. (2005), který srovnával reliabilitu testování izometrické síly při flexi v LK $\left(90^{\circ}\right) \mathrm{s}$ pevným dynamometrem (Isobex 2.1.). U skupiny dvaceti testovaných zjistili vyšší hodnoty ICC při použití pevného dynamometru $(0,98)$ než u ručně drženého dynamometru $(0,95)$. U ručně drženého dynamometru mohla být chyba při měření způsobena nestabilitou držení dynamometru a jiného umístění snímačů na měřenou část končetiny. ICC převyšuje naše hodnoty pouze pro flexi v LK. V našem případě byly vyšší hodnoty ICC díky užití fixního dynamometru.

Smith et al. (2001) se zabývali měřením maximální izometrické kontrakce na izokinetickém dynamometru Kin-Com 125AP, kde reliabilita izometrické síly byla vyjádřena pomocí ICC mezi dvěma pokusy (24-72h mezi pokusy). Horní končetina se nalézala ve $45^{\circ}$ od těla a stejný úhel svíralo rameno a loket. Hodnota ICC pro interní a externí rotaci byla rovna stejné hodnotě 0,97 . Naše hodnoty ICC dosahovaly rozmezí $0,76-0,96$, jednalo se však o podobný pohyb jako $\mathrm{v}$ předchozí studii. Střední chyba měření byla počítána zvlášt pro muže a ženy celkového průměrného věku 27,7 let. Pro interní a externí rotaci byla zaznamenána hodnota střední chyby měření 3,6 a 2,5 $\mathrm{N}^{\star} \mathrm{m}$ pro muže a pro ženy 1,7 a $1,0 \mathrm{~N}^{\star} \mathrm{m}$ (Smith et al., 2001). Rozdělením mužů a žen se zmenšil skupinový rozptyl, a proto můžeme usuzovat i nižší hodnoty SEM než v našem prŕípadě, kdy skupina nebyla hodnocena v závislosti na pohlaví.

\section{Reliabilita měření v kolenním kloubu}

Také $\mathrm{v}$ př́ípadě měření maximální izometrické kontrakce $\mathrm{v}$ kolenním kloubu se používá ručně držený dynamometr. V př́padu studie Dunna a Iversena (2003) byla reliabilita měření zjištována u skupiny starších jedinců o průměrném věku 68,2 $\pm 7,7$ let. Hodnoty ICC pro flexi v KK u pravé a levé končetiny byly 0,91 a 0,93 . Pro extensory v KK se ICC pohyboval 0,92 pro pravou končetinu a 0,87 pro levou. SEM se pohybovala pro flexory $0,92-1,03 \mathrm{~kg}$ a extenzory $1,04-1,35 \mathrm{~kg}$ (Dunn a Iversen, 2003). Jednalo se o skupinu starších osob s degenerativní chorobou zad. Věk jedinců, jejich choroba nebo použití ručně drženého dynamometru mohly mít vliv na nižší hodnoty koeficientů reliability, i přesto jsou hodnoty ICC poměrně vysoké. $V$ našem př́ípadě jsou výsledky o něco vyšší $(0,90-0,95)$, pravděpodobně $\mathrm{z}$ důvodu nižšího věku testovaných.

Při použití izokinetického dynamometru značky Con-Trex pro měření maximální izometrické síly byly zjištěny excelentní hodnoty ICC pro flexi a extenzi v KK a to 0,97-0,99 (Maffiuletti et al., 2007). Jednalo se o skupinu 15 mužů a 15 žen ve věku $30 \pm 5$ let. Výsledky byly hodnoceny pouze pomocí ICC, proto nemůžeme srovnávat hodnoty $r$ ani SEM. Dvě studie (Cannon et al., 2008; Phillips et al., 2000) se zabývaly měřením izometrické síly v KK na izokinetickém dynamometru značky Kin-Com. U skupiny 20-30letých žen se ICC nacházelo na 0,94 a $r$ se rovnalo 0,91 při $75^{\circ}$ kolenní flexi (Cannon et al., 2008). Tyto hodnoty ICC i $r$ se téměř shodovaly s naší studií. Jednalo se téměř o věkově a početně shodnou skupinu, jediným rozdílem byl úhel v KK. Podobné hodnoty ukázaly minimální vliv velikosti úhlu $\left(90^{\circ}\right.$ vs. $75^{\circ}$ ) na velikost koeficientů. Phillips et al. (2000) se zaměřili na izometrickou sílu KK při $60^{\circ}$ flexi u skupiny 8 mužů a 12 žen ve věku 20-39 let. ICC pro flexi v KK bylo 0,82-0,90 a extenzi 0,86-0,96 pro nedominantní a dominantní končetinu. Ve většině př́padů kromě jednoho byla dominantní končetina pravá jako v našem prŕpadě. Velikost koeficientů je podobná opět i přes jiný úhel v KK.

\section{Reliabilita měření při pohybech trupu}

Reliabilita testování síly při rotaci trupu vsedě byla o něco nižší než v př́padě horních a dolních končetin. Faktorem mohla být únava způsobena předchozím měřením horních a dolních končetin. Velikost koeficientů závisí také na použitém přístroji. Na Biodexu Multi-joint System 3 pro vzpřimovače byly zjištěny koeficienty ICC pro muže od 0,91-0,92 a pro ženy 0,87-0,92 (McIntire et al., 2007). V jiné studii (Peolsson et al., 2001) byla reliabilita měření izometrické síly vzpřimovačů trupu a hlavy určena také pomocí ICC a hodnoty se pohybovaly v rozmezí $0,94-0,97$. ICC v naší studii pro pohyby trupu bylo daleko nižší $(0,75-0,85)$. Důvodem mohla být jiná pozice (vestoje) než v předchozí uváděné práci. Rozdílnost 
výsledků reliability $\mathrm{v}$ našem př́padě mohla být způsobena použitím sešitého popruhu mezi trupem a snímačem. $\mathrm{V}$ uvedené studii bylo testování prováděno vsedě na izometrickém dynamometru DBC 140 se zaměřením na flexi a extenzi páteře a úklon vpravo a vlevo u skupiny 30 dobrovolníků ve věku 20-58 let (Peolsson et al., 2001).

\section{Závěry}

ICC pro opakované měření maximální izometrické síly pomocí dynamometru Vishay Tedea-Huntleigh Model 1042 se pro flexi a extenzi v LK rovná hodnotám 0,76-0,96 a 0,95-0,96, pro flexi a extenzi KK 0,90-0,95, pro předklon a úklony trupu 0,$85 ; 0,75$ a 0,85 . V prŕpadech flexe a extenze LK a KK se hodnotami ICC přibližujeme studiím, které se rovněž zabývaly maximální volní izometrickou kontrakcí. Rozdílné ICC shledáváme u měření trupu, kde naše hodnoty jsou nižší než v jiných studiích. Ve srovnání s jinými studiemi můžeme naše hodnoty reliability považovat za velmi dobré. Velikost reliability končetin mủžeme řadit mezi vysoké a střední chyba měření je závislá na poloze účastníka při měření. Koeficienty reliability měření síly trupu řadíme mezi středně vysoké a střední chyba je větší než v př́ipadě měření horních a dolních končetin.

\section{Literatura}

ATKINSON, G., NEVILL, A. M. Statistical methods for assessing measurement error (reliability) in variables relevant to sports medicine. Sports Medicine, 1998, vol. 26, no. 4, s. 217-238.

ATKINSON, G., NEVILL, A. M. Typical error versus limits of agreement. Sports Medicine, 2000, vol. 30, no. 5, s. 375-381.

BAUMGARTNER, T. A. Estimating the stability reliability of a score. Measurement in physical education and exercise science, 2000, vol. 4, no. 3, s. 175-178.

BAUMGARTNER, T. A., JACKSON, A. S. Measurement for evaluation in physical education and exercise science. Madison,WI.: WCB/McGraw-Hill, 2003.

BLAHUŠ, P. K systémovému pojetí statistických metod v metodologii empirického výzkumu chování. Praha: Karolinum, 1996.

80-7184-100-5.

BLAHUŠ, P. K teorii testování pohybových schopností. Praha: Univerzita Karlova, 1976.

CANNON, J., KAY, D., TARPENNING, K. M.et al. Reproducibility and changes in twitch properties associated with age and resistance training in young and elderly women. Scandinavian Journal of Medicine \& Science in Sports, 2008, vol. 18, no., s. 627-635.

DAWSON, C., CROCE, R., QUINN, T.et al. Reliability of the Nicholas Manual Muscle Tester on Upper body strength in children ages 8-10. Pediatric Exercise Science, 1992, vol. 4, no., s. 340-350.

DUNN, J. C., IVERSEN, M. D. Interrater Reliability of Knee Muscle Forces Obtained by Hand-held Dynamometer from Elderly Subjects with Degenerative Back Pain. Journal of Geriatric Physical Therapy, 2003, vol. 26, no. 3, s. 23-29.

HENDL, J. Přehled statistickým metod zpracování dat. Praha: Portál, 2004.

80-7178-820-1.

HEYWARD, V. H. Advanced fitness assessment and exercise prescription. Champaign, IL.: Human Kinetics, 2010.

0-7360-8659-5.

HOPKINS, W. G. Measures of reliability in sports medicine and science. Sports Medicine, 2000, vol. 30, no. 1, s. 1-15.

MAFFIULETTI, N. A., BIZZINI, M., DESBROSSES, K.et al. Reliability of knee extension and flexion measurements using the Con-Trex isokinetic dynamometer. Clinical Physiology and Functional Imaging, 2007, vol. 27, no., s. 346-353.

MCINTIRE, K., ASHER, M., BURTON, D.et al. Development of a protocol for isometric trunk rotation strength testing and strength asymmetry assessment. Isokinetics and Exercise Science, 2007, vol. 15, no., s. 183-194. 
MĚKOTA, K., BLAHUŠ, P. Motorické testy v tělesné výchově. Praha: Státní pedagogické nakladatelství, 1983.

PEOLSSON, A., ÖBERG, B., HEDLUND, R. Intra- and inter-tester reliability and reference values for isometric neck strength. Physiotherapy Research International, 2001, vol. 6, no. 1, s. 15-26.

PHILLIPS, B. A., LO, S. K., MASTAGLIA, F. L. Isokinetic and isometric torque values using a Kin-Com dynamometer in normal subjects aged 20 to 69 years. Isokinetics and Exercise Science, 2000, vol. 8, no., s. $147-159$.

SHROUT, P. E., FLEISS, J. L. Intraclass correlations: uses in assessing rater reliability. Psychological Bulletin, 1979, vol. 36, no., s. 420-428.

SMITH, J., PADGETT, D. J., KOTAJARVI, B. R.et al. Isokinetic and isometric shoulder rotation strength in the protracted position: A reliability study Isokinetics and Exercise Science, 2001, vol. 9, no., s. 119-127. STREJCOVÁ, B., BALÁŠ, J., SUSS, V. Reliabilita testování silových schopností na izokinetickém a izometrickém dynamometru. Česká kinantropologie, 2010, vol. 14, no. 3, s. 94-100.

THOMAS, J. R., NELSON, J. K. Research Methods in Physical Activity. Champaign: Human Kinetics, 1996.

0-88011-481-9.

VERMEULEN, H. M., DEBOCK, G. H., VANHOUWELINGEN, H. C.et al. A comparison of two portable dynamometers in the assessment of shoulder and elbow strength. Physiotherapy, 2005, vol. 91, no., s. $101-112$.

WEIR, J. P. Quantifying test-retest reliability using the intraclass correlation coefficient and the SEM. Journal of Strength and Conditioning Research, 2005, vol. 19, no. 1, s. 231-240. 